\title{
The Effects of Derelict Blue Crab Traps on Marine Organisms in the Lower York River, Virginia
}

\author{
Kirk J. Havens,* Donna Marie Bilkovic, Dave Stanhope, Kory Angstadt, \\ AND CARL Hershner \\ Center for Coastal Resources Management, Virginia Institute of Marine Science, \\ College of William and Mary, Post Office Box 1346, Gloucester Point, Virginia 23062, USA
}

\begin{abstract}
Derelict (abandoned or lost) traps targeting blue crab Callinectes sapidus have the potential to affect the blue crab fishery and other marine-oriented species. We used sidescan sonar to locate derelict traps and assess their extent and accumulation rate. Experimental traps were monitored at four locations to calculate catch rates of marine organisms and trap degradation rates. In 2006, 635-676 derelict traps were identified in a $33.5-\mathrm{km}^{2}$ area of the lower York River in Virginia's portion of the Chesapeake Bay. Trap loss rates are estimated at $30 \%$, resulting in the potential addition of over 100,000 traps annually to the Chesapeake Bay derelict trap population in Virginia. The top four species captured in the experimental traps were blue crab, Atlantic croaker Micropogonias undulates, oyster toadfish Opsanus tau, and white perch Morone americana. Experimental derelict traps captured 50.6 blue crabs $\cdot \operatorname{trap}^{-1} \cdot$ season $^{-1}$ during April-November 2006 and 13.6 Atlantic croakers $\cdot \operatorname{trap}^{-1} \cdot$ season $^{-1}$ during May-August 2006. There was no difference in catch rates between traps of different ages. Baiting traps to simulate entrapped fish (self-baiting) doubled the catch rate. Experimental derelict traps continued to capture organisms for at least 1 year, which suggests that derelict traps could affect blue crab populations.
\end{abstract}

The number of derelict traps targeting blue crab Callinectes sapidus in the nation's estuaries is unknown. Typically, traps become lost when buoy lines are severed by vessel propellers, lines break because of age, choice of buoy material is poor, traps are abandoned, traps are vandalized, or storms roll the traps, pulling the buoy below the surface. In Florida, Alabama, Mississippi, and Louisiana, estimates derived from calculations of trap loss suggest that derelict traps numbered at 605,000 in 1993 , although Guillory and Perret (1998) stated that this number probably was an underestimate. Guillory et al. (2001), using an annual total of 1 million traps fished commercially and a $25 \%$ loss-abandonment rate, suggested that 250,000 derelict traps are added to the Gulf of Mexico annually.

The blue crab is considered an important component of the Chesapeake Bay, both ecologically and eco-

\footnotetext{
* Corresponding author: kirk@vims.edu
}

Received January 23, 2007; accepted December 17, 2007 Published online August 21, 2008 nomically. This species is considered the foremost benthic scavenger and predator (Baird and Ulanowicz 1989), and Chesapeake Bay stocks provided $80 \%$ of the U.S. blue crab catch in the 1950s (Miller et al. 2005). However, a steady decrease in landings has occurred over the last few decades (Miller 2001a, 2005). According to commercial landings, the Chesapeake Bay is still the nation's largest source of blue crabs (30\% in 2003), but Virginia has dropped to fourth (Miller et al. 2005). Nonetheless, the blue crab fishery still accounts for over US\$200 million annually for the Chesapeake Bay region (Miller 2001b).

Lost or abandoned (derelict) commercial fishing gear, including nets and traps, present safety, nuisance, and environmental effects in estuarine waters. Blue crabs and various fish species that are entrapped and die in derelict traps can act as an attractant to crabs, resulting in a self-baiting effect. Derelict fishing gear damages sensitive habitat and continues to capture both target and bycatch species, leading to reduced fitness and significant acute and delayed mortalities (High and Worlund 1979; Guillory 1993, 2001; Bullimore et al. 2001; Matsuoka et al. 2005). Animals captured in derelict traps experience starvation, cannibalism, infection, disease, or prolonged exposure to poor water quality (i.e., low dissolved oxygen; Van Engel 1982; Guillory 1993). The effect of derelict blue crab traps on diamondback terrapin Malaclemys terrapin and commercially important finfish has been documented (Smolowitz 1978; Guillory 1993; Guillory and Prejean 1997; Roosenburg et al. 1997). In the Gulf of Mexico, evidence that derelict traps contribute to significant mortalities in the blue crab fishery has prompted the development of removal strategies to reduce the ecological and economic impacts of derelict traps (Guillory et al. 2001).

Information regarding the amount and effect of derelict traps in the Chesapeake Bay is limited. An examination of existing derelict trap data retrieved from Chesapeake Bay Multispecies Monitoring and Assessment Program (ChesMMAP; Bonzek and Latour 2005) trawl surveys shows the potential effect of derelict traps on nekton in Virginia waters. During surveys from April to October 2002-2005, 91 derelict 
traps were ensnared and their catches were documented. Fourteen nekton species (162 animals) were captured with the traps, including the following economically important species (in order of abundance): blue crab, Atlantic croaker Micropogonias undulates, spot Leiostomus xanthurus, scup Stenotomus chrysops, white perch Morone americana, black seabass Centropristis striata, red hake Urophycis chuss, striped bass Morone saxatilis, bluefish Pomatomus saltatrix, and summer flounder Paralichthys dentatus (Bonzek and Latour 2005).

Casey (1990) suggested that commercial trap losses in the Chesapeake Bay are as high as 30\% per fisherman. In 2005, Virginia issued 1,524 blue crab commercial trapping licenses (not including peeler trap licenses) for a potential total of 368,900 traps (VMRC 2006). The Virginia commercial blue crab trapping season extends from March 18 to November 30. It is unlikely, however, that all the legally deployable traps are actually deployed.

McBride (2006) stated that

... lost and abandoned crab pots not only represent a direct economic loss to fishermen, but also pose attractive refuge sites that trap and eventually may kill significant numbers of crabs and finfish.

In an independent review of the 2005 Stock Assessment for the Blue Crab (Miller et al. 2005), Haddon (2005) recommended that

...experiments and observations be designed to investigate the potential mortality arising through the agency of ghost fishing by self-baiting lost crab pots. If this is found to be significant then options for ameliorating the problem should be developed.

To address the effect of derelict traps on marine organisms, we investigated the following questions in the lower York River, Virginia: (1) how many derelict traps are present and what is the annual trap loss rate; (2) how long do derelict traps continue to effectively capture organisms; (3) what marine organisms are being trapped; and (4) how does self-baiting of traps affect catch?

\section{Methods}

Active and derelict blue crab trap surveys.-Both active and derelict traps were assessed in two regions of the lower Chesapeake Bay to determine the fishing pressure and presence of derelict gear. Survey locations were selected on the basis of known fishing pressure in Virginia (W. Rhodes, Virginia Marine Resources Commission, personal communication). During the crabbing season in October 2006, boat surveys were conducted and Global Positioning System coordinates

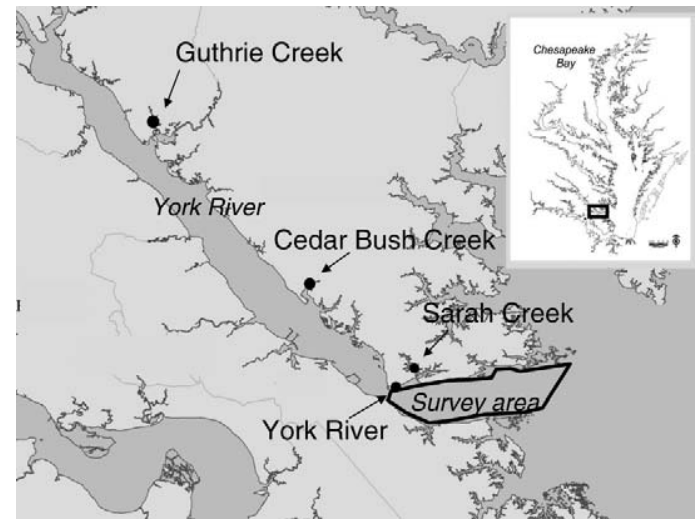

FIGURE 1.-Location of the York River, Virginia, survey area and experimental trap sites in the Chesapeake Bay, where the effects of derelict blue crab traps were studied.

were recorded for buoyed (active) traps over approximately $33.3 \mathrm{~km}^{2}$ in the main-stem lower York River and approximately $0.2 \mathrm{~km}^{2}$ in an adjacent tributary, Sarah Creek (Figure 1).

The number of derelict blue crab traps was estimated in a benthic mapping survey of the same area during nonfishing time periods (York River: January-February 2006; Sarah Creek: November 2005, resurveyed January-February 2006) Side-scan sonar technology mounted to the vessel hull was utilized (Marine Sonics Sea Scan; $600-\mathrm{kHz}$ transducer) to collect real-time, georeferenced data with overlapping edges matched to form a continuous profile of the bottom. The surveys were completed in 100-m swaths with $20 \%$ overlap of tracks. This equipment provided high-resolution digital images of blue crab traps. Georeferenced trap images were converted to Geographic Information Systems shape files. Ground-truth activities to test the accuracy of trap identification included removing targets in Sarah Creek identified from side-scan sonar images as derelict traps. Potential errors in image identification were estimated from the ratio of suspected derelict traps identified by side-scan sonar to field-verified derelict traps. Derelict traps were retrieved by boat using Global Positioning System coordinates obtained from the side-scan sonar and a grappling hook. Nekton species captured in the derelict traps that were removed from the system were enumerated and measured. The ratio of derelict : buoyed (active) traps was used to estimate fishing pressure and potential trap loss. To assess the potential for annual trap loss, we surveyed the Sarah Creek site in the nonfishing season (fallwinter 2005), removed derelict traps, and resurveyed the area in July 2006 for both active and derelict traps. Trap loss rates were estimated by assessing the 


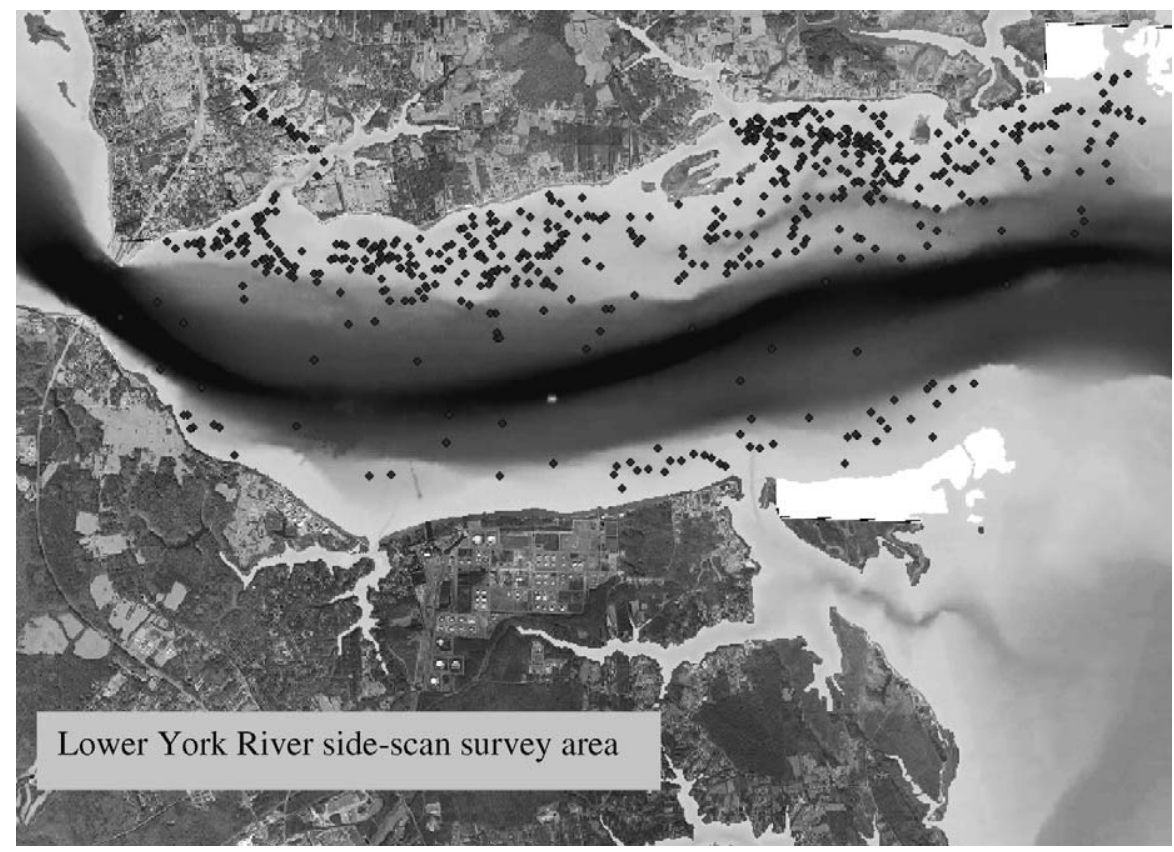

FIGURE 2.-Locations of 676 potentially derelict blue crab traps identified through side-scan sonar in the lower York River, Virginia (aerial imagery source: Commonwealth of Virginia 2002).

numbers of active and derelict traps over subsequent years.

Experimental design 1: trap degradation, encrustation, and catch rates.-To test trap degradation rates and blue crab catch rates, we purchased 28 unbaited, vinyl-coated, fully outfitted (escape-cull ring, rebar weight, zinc anode) traps from a commercial trap company and deployed them in November 2005 to four areas of the York River across an average annual salinity gradient of $5.9-20.0 \%$; depth ranged from constantly submerged to periodic exposure at low tide (Figure 1). Twenty-eight additional traps were deployed to the same sites on April 2006. November and April deployment dates were selected to mimic conditions in traps lost at the end of the crabbing season (November) or at the beginning of the crabbing season (April) in Virginia. Trap entrance funnels were modified to allow the funnels to be closed. The funnel entrances were opened for $7 \mathrm{~d}$ of each month (from November 2005 to November 2006 for the first sample set [old]; and from April to November 2006 for the second sample set [new]). Traps were opened and weighed (wet weight, $\mathrm{kg}$ ) to measure the amount and rate of encrustation, which could affect catch rates and lead to trap collapse. Trap condition was noted on the first day of fishing; all organisms were counted, identified, measured, and released on the second, fourth, and seventh day of fishing. On the seventh day, the entrance funnels on all traps were closed, redeployed, and left undisturbed until the next sampling date. Temperature and salinity measurements were taken monthly at each experimental site with a hand-held YSI Sonde. Daily catches over the 7-d period of each month for each site were averaged, and the entire seasonal average was determined for the period of blue crab capture in traps (April-October; only three blue crabs were captured during NovemberMarch). Catch rates between sites and between traps of different ages were compared by using a general linear model procedure to conduct a two-way analysis of variance (ANOVA) with replication, examining the effects of the individual fixed factors, age of traps and site, and the interactions between factors. Pairwise multiple comparisons of sites were completed with Tukey's honestly significant difference test (Statistical Package for the Social Sciences version 13.0).

Experimental design 2: baited versus unbaited trap catch rates.-To test the self-baiting phenomenon, we compared catch rates between unbaited and baited traps. Fourteen traps were deployed in two locations during August and September: (1) a low-salinity site (Guthrie Creek; average salinity $=5.9 \%$ ) and (2) a higher-salinity site (Sarah Creek; average salinity = 19.8\%o). Seven traps at each site were baited with a 
dead Atlantic croaker in the upper chamber to simulate the capture of a fish by a derelict trap; the other seven traps were left unbaited. After $5 \mathrm{~d}$, all traps were checked and the entrapped organisms were identified, measured, and released. Differences in blue crab catch rates for baited and unbaited traps were compared by using one-way ANOVA (Minitab).

\section{Results}

\section{Surveys: Active and Derelict Trap Density}

Side-scan surveys identified 676 potentially derelict trap targets. Ninety-four percent (16 of 17) of a subset of side-scan sonar targets in Sarah Creek were correctly identified as derelict blue crab traps, thus resulting in a $6 \%$ identification error. Of the suspected derelict traps, 89 (approximately 14\%) were considered abandoned rather than lost because attached floating buoys were present and the traps were identified during the closed season. Of the 33 derelict traps removed from the York River, 27 (82\%) were deemed to still be functional. Surveys of active and derelict traps in the entire lower York River $\left(33.5 \mathrm{~km}^{2}\right)$, including Sarah Creek, located 635-676 potentially derelict traps (taking into account the $6 \%$ possible identification error) and 905 active, buoyed traps (863 in the lower York River and 42 in Sarah Creek; Figure 2).

The in-season census of Sarah Creek identified 40 buoyed traps in 2005 and 42 buoyed traps in 2006. After the closure of the blue crab trapping season, 16 traps located by side-scan sonar were identified as derelict and were removed from the system in December 2005. Resurvey of the area in July 2006 identified 12 derelict traps. The trap loss rate in Sarah Creek was thus $22 \%$ for 2006. This may be an underestimation of the annual derelict trap population in Sarah Creek, however, because the survey took place in the middle of the crabbing season and additional traps could have been lost near the end of the season. The ratio of derelict : buoyed traps in Sarah Creek was 16:40 (40\%) in 2005 and 12:54 (22.2\%) in 2006.

\section{Results of Experimental Design 1: Trap Encrustation and Degradation}

Traps continued to fish up to the end of the 13month study period, despite being encrusted periodically with fouling organisms. Traps followed fouling trends of a gradual increase in weight over time. However, traps in the lower York River main stem gained weight rapidly in the spring and then lost weight in the late summer as a result of growth and dieback of tunicates Mogula spp. in an established pattern (McDougall 1943; Figure 3). Other trap-fouling organisms included barnacles Balanus spp., tube weeds

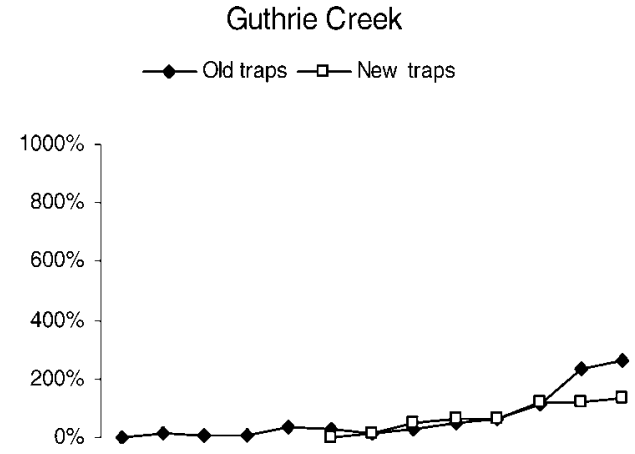

Sarah Creek

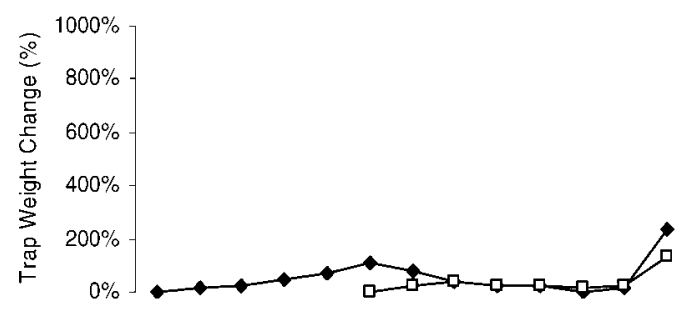

York River

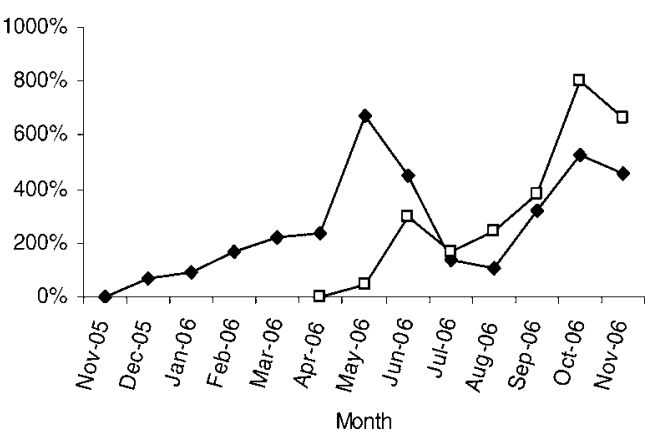

FIGURE 3.-Percent change in blue crab trap wet weight $(\mathrm{kg})$ versus initial trap weight in Guthrie Creek (low-salinity site), Sarah Creek (high-salinity site), and the York River (high-salinity site), Virginia.

Polysiphonia spp., red beard sponge Microciona prolifera, and hydroids Bougainvillia carolinensis. The traps in the low-salinity site, Guthrie Creek, were predominantly fouled with hydroids. Shively (1997) reported that depending on salinity, the life expectancy of vinyl-coated traps will average 2 years or more.

Blue crab catch rates. - The overall blue crab catch rate for the experimental traps was 0.24 blue 
TABLE 1.-Mean (SE) trap catch rates (blue crabs $\cdot \operatorname{trap}^{-1}$. $\mathrm{day}^{-1}$ ) at four experimental sites in the York River system, Virginia.

\begin{tabular}{lccc}
\hline \multicolumn{1}{c}{ Site } & $\begin{array}{c}\text { Catch rate } \\
\left(\text { blue crabs } \text { trap }^{-1} \cdot \text { day }^{-1}\right)\end{array}$ & $\begin{array}{c}\text { Average } \\
\text { salinity (\%o) }\end{array}$ & $\begin{array}{c}\text { Trap days } \\
(\text { Apr-Oct) }\end{array}$ \\
\hline Guthrie Creek & $0.26(0.08)$ & 5.9 & 673 \\
Cedar Creek & $0.27(0.08)$ & 16.2 & 686 \\
Sarah Creek & $0.20(0.06)$ & 19.8 & 684 \\
York River & $0.21(0.09)$ & 20.0 & 625 \\
\hline
\end{tabular}

crabs $\cdot \operatorname{trap}^{-1} \cdot \mathrm{d}^{-1}$ for an average of 50.6 blue crabs/trap over the 7-month period (Table 1). A review of the ChesMMAP derelict trap data shows that the catch rate (averaged over 2002, 2003, and 2005) was 0.42 blue crabs $\cdot \operatorname{trap}^{-1} \cdot \mathrm{d}^{-1}$ (Bonzek and Latour 2005). The single-day catch rate for the 33 York River derelict traps removed in August 2006 was 0.65 blue crabs/ trap. There were no significant differences (general linear model two-way ANOVA) in catches between traps of different ages (first versus second sample set: $P$ $=0.538)$, between sites $(P=0.168)$, or as an interactive effect $(P=0.775$; Table 2).

Species trapped.-From November 2005 to October 2006, 641 blue crabs and 172 fish were captured in the experimental traps. In the York River, $12 \%$ of the trapped female blue crabs were egg-bearing. Eleven fish species were observed throughout the experimental sites; economically important Atlantic croaker accounted for the highest proportion $(29.7 \%)$ of the finfish catch (Table 3). The average catch rate for Atlantic croaker in the lower York River during the summer season (May-August 2006) was 0.11 fish$\operatorname{trap}^{-1} \cdot \mathrm{d}^{-1}$.

Species trapped in the York River experimental site were similar to species noted from derelict traps recovered from the York River during August 2006 (Table 4), and the total catch of blue crabs was $30 \%$ in traps at the experimental site and $34 \%$ in traps recovered during August 2006.

\section{Experimental Design 2: Blue Crab Catch Rates in Baited versus Unbaited Traps}

Catch rates of baited and unbaited traps varied significantly (one-way ANOVA: $\mathrm{df}=42, P=0.016$ ); the mean blue crab catch rate was slightly more than double in simulated self-baiting traps $(0.79$ blue crabs $\left.\cdot \operatorname{trap}^{-1} \cdot \mathrm{d}^{-1}\right)$ than in unbaited traps $(0.39$ blue crabs $\cdot \operatorname{trap}^{-1} \cdot \mathrm{d}^{-1}$ ).

\section{Discussion}

Side-scan technology was effective at locating and identifying derelict blue crab traps and can be used to determine the density and accumulation rates of derelict traps. In the lower York River, a significant proportion of traps in the system is derelict (635-676 derelict traps versus 905 buoyed traps), and traps are continually being added to the derelict trap population.

In addition, derelict traps have the potential to persist and continue to entrap blue crab and fish. The traps located in the higher-salinity zone were periodically encrusted with tunicates, barnacles, and hydroids to a higher degree than the traps located in the lowersalinity zones; this suggests that trap degradation (i.e., from encrustation) and trap collapse will occur faster in higher-salinity areas. However, encrustation of the traps was cyclic and traps were still effective at trapping organisms after 1 year.

Although traps continue to trap organisms after becoming derelict, they also serve as habitat. Several species (lined seahorse Hippocampus erectus, northern pipefish Syngnathus fuscus, feather blenny Hypsoblennius hentz, and juvenile blue crab) were observed utilizing the encrusted experimental traps. At some point in time, the traps will degrade to such an extent that trapping of organisms ceases and the traps serve entirely as habitat. The present study suggests that the length of time for degradation to reach a level of noneffectiveness in trapping is at least longer than 1 year in high-salinity areas and probably much longer in lower-salinity areas.

TABLE 2.- Two-way analysis of variance comparison of blue crab catch rates between derelict traps of different ages (old or new) and among traps in four areas of the York River system, Virginia, 2005-2006 $\left(\eta_{p}^{2}=\right.$ partial eta squared; used to estimate the amount of variance in the dependent variable that can be explained by each independent variable).

\begin{tabular}{lcrrrrr}
\hline \multicolumn{1}{c}{ Source } & Type III sum of squares & df & Mean square & $F$ & $P$ & $\eta_{p}^{2}$ \\
\hline Corrected model & $0.055^{\mathrm{a}}$ & 7 & 0.008 & 0.967 & 0.466 & 0.124 \\
Intercept & 3.102 & 1 & 3.102 & 378.376 & 0.000 & 0.887 \\
Age of trap & 0.003 & 1 & 0.003 & 0.384 & 0.538 & 0.008 \\
Site & 0.043 & 3 & 0.014 & 1.757 & 0.168 & 0.099 \\
Age of trap $\times$ site & 0.009 & 3 & 0.003 & 0.370 & 0.775 & 0.023 \\
Error & 0.394 & 48 & 0.008 & & & \\
Total & 3.551 & 56 & & & & \\
Corrected total & 0.449 & 55 & & & & \\
\hline
\end{tabular}

${ }^{\text {a }} R^{2}=0.124$ (adjusted $\left.R^{2}=-0.004\right)$. 
TABLE 3.-Abundances of fish, reptiles, and mammals captured in derelict blue crab traps and percentage of catch (within each category) contributed by each species at four experimental sites in the York River system, Virginia, during November 2005-October 2006.

\begin{tabular}{lcc}
\hline \multicolumn{1}{c}{ Species } & Abundance & Percent of catch \\
\hline Nekton & & \\
Blue crab (male) & 486 & 59.8 \\
Blue crab (female) & 155 & 19.1 \\
Atlantic croaker & 51 & 6.3 \\
Oyster toadfish Opsanus tau & 34 & 4.2 \\
White perch & 29 & 3.6 \\
White catfish Ameiurus catus & 16 & 2.0 \\
Spot & 15 & 1.8 \\
Blue catfish Ictalurus furcatus & 9 & 1.1 \\
Red drum Sciaenops ocellatus & 9 & 1.1 \\
Black seabass & 3 & 0.4 \\
Sheepshead Archosargus & & \\
$\quad$ probatocephalus & 3 & 0.4 \\
Summer flounder & 2 & 0.2 \\
Pumpkinseed Lepomis gibbosus & 1 & 0.1 \\
Reptiles and mammals & & \\
Muskrat Ondatra zibethicus & 6 & 75.0 \\
Eastern mud turtle Kinosternon & & \\
$\quad$ subrubrum & 1 & 12.5 \\
Diamondback terrapin & 1 & 12.5 \\
\hline
\end{tabular}

The effect of derelict traps on marine organisms has been documented by several researchers (see Guillory et al. 2001). In a review of several derelict trap studies in the Chesapeake Bay, Guillory et al. (2001) reported a trap mortality of 7.5 blue crabs/trap for August and September. This compares with our average catch rates of 8.7 and 12.6 blue crabs/trap for August and September 2006, respectively. Studies conducted in South Carolina concluded that the total annual mortality of derelict traps ranged from 20 to 60 blue crabs/trap (average $=40$ blue crabs/trap; Whitaker 1979). Poon (2005), in a review of published blue crab mortality rates for derelict traps, calculated an average of 53.8 blue crabs $\cdot \operatorname{trap}^{-1} \cdot$ year $^{-1}$. Data from this study suggest that the 521-554 functional derelict traps in the lower York River capture a seasonal average of 50.6 blue crabs/trap (total $=26,363-28,032$ blue crabs) and 13.6 Atlantic croakers/trap (total $=7,086-7,534$ fish). The self-baiting phenomenon could result in a doubling of the number of blue crabs trapped. In the York River, $12 \%$ of the captured female blue crabs were eggbearing. Mature females stay predominantly in shallow subestuaries and the margins of the main-stem Chesapeake Bay, moving at or near the bottom (Turner et al. 2003). Migratory patterns and existing crabbing practices make a large segment of the spawning stock vulnerable to intensive fishing pressure (Lipcius and Stockhausen 2002), a result that may be exacerbated by a large derelict trap population.

A few studies have attempted to calculate annual trap loss numbers. Casey (1990) suggested a loss of $30 \%$ for the Chesapeake Bay. Our study found an average annual ratio of $31.1 \%$ (derelict : buoyed traps) and a 2006 trap loss rate of $22 \%$ for Sarah Creek. In addition, if the fishing pressure of approximately 900 traps in the lower York River and Sarah Creek is consistent from year to year and if the life of a derelict trap in this area is approximately two seasons, then the trap loss rate in the lower York River averages approximately $30 \%$. If the $30 \%$ loss rate is representative for the Virginia portion of the Chesapeake Bay, then the potential annual accumulation of derelict blue crabs traps could be over 100,000 . We note, however, that several kinds of events, ranging from severe climatic activity (or lack thereof) to increased recreational use, could modify this number.

Information on blue crab trap escape rates, fishing pressure versus trap loss, and blue crab mortality in derelict traps will be important to help quantify the effects of derelict traps on the overall blue crab population. In addition, investigation of other regions of the Chesapeake Bay under a range of fishing pressures will be necessary to determine whether the patterns observed in the lower York River are similar throughout the Chesapeake Bay.

TABLE 4.-Comparison of abundances and catch percentages between fish species trapped in derelict blue crab traps recovered from the York River, Virginia (August 8, 2006), and species captured in York River experimental traps (August 2-7, 2006).

\begin{tabular}{lccccc}
\hline & \multicolumn{2}{c}{ Experimental traps } & & \multicolumn{2}{c}{ Derelict traps } \\
\cline { 2 - 3 } \cline { 5 - 6 } \multicolumn{1}{c}{ Species } & Abundance & Percent of catch & & Abundance & Percent of catch \\
\hline Blue crab & 18 & 30 & & 11 & 34 \\
Atlantic croaker & 26 & 45 & & 7 & 22 \\
Spot & 9 & 15 & & 2 & 6 \\
Oyster toadfish & 5 & 8 & & 6 & 19 \\
Black seabass & 1 & 1 & & \\
Summer flounder & 0 & 0 & & 1 & 3 \\
Pigfish Orthopristis chrysoptera & 0 & 1 & & 1 & 3 \\
White perch & 1 & & & 0 & 0 \\
\hline
\end{tabular}




\section{Acknowledgments}

We thank a number of people who contributed to the project. Jeff June, Crayton Fenn, Steve Giordano, Jay Lazar, and Doug Levin provided valuable technical advice. Dave Weiss, Molly Roggero, Dawn Fleming, Harry Berquist, Tami Rudnicky, Sharon Killeen, and Marcia Berman were extremely helpful in the field. This project was supported by funding from the National Oceanic and Atmospheric Administration (NOAA) Marine Debris Program through the NOAA Chesapeake Bay Program Office and the National Fish and Wildlife Foundation. The manuscript benefited from the comments of Carolyn Griswold, Whitney Grogan, and two anonymous reviewers. This is Virginia Institute of Marine Science contribution 2896.

\section{References}

Baird, D., and R. E. Ulanowicz. 1989. Seasonal dynamics of the Chesapeake Bay ecosystem. Ecological Monographs 59:329-364.

Bonzek, C. F., and R. J. Latour. 2005. Chesapeake Bay Multispecies Monitoring and Assessment Program. Virginia Institute of Marine Science, Gloucester Point, Virginia. Available: www.fisheries.vims.edu. (December 2006).

Bullimore, B. A., P. B. Newman, M. J. Kaiser, S. E. Gilbert, and K. M. Lock. 2001. A study of catches in a fleet of "ghost-fishing" pots. U.S. National Marine Fisheries Service Fishery Bulletin 99:247-253.

Casey, J. 1990. A review of biodegradable escape panels in crab pots. Maryland Department of Natural Resources, Tidal Fisheries Technical Report Series Number 10, Annapolis.

Guillory, V. 1993. Ghost fishing in blue crab traps. North American Journal of Fisheries Management 13:459-466.

Guillory, V. 2001. A review of incidental fishing mortalities of blue crabs. Pages 28-41 in V. Guillory, H. M. Perry, and S. Vanderkooy, editors. Proceedings of the blue crab mortality symposium. Gulf States Marine Fisheries Commission, Ocean Springs, Mississippi.

Guillory, V., A. McMillen-Jackson, L. Hartman, H. Perry, T. Floyd, T. Wagner, and G. Graham. 2001. Blue crab derelict traps and trap removal programs. Gulf States Marine Fisheries Commission, Ocean Springs, Mississippi.

Guillory, V., and W. E. Perret. 1998. Management, history, and status and trends in the Louisiana blue crab fishery. Journal of Shellfish Research 17:413-424.

Guillory, V., and P. Prejean. 1997. Blue crab trap selectivity studies: mesh size. U.S. National Marine Fisheries Service Marine Fisheries Review 59:29-31.

Haddon, M. 2005. Review of the Chesapeake Bay blue crab (Callinectes sapidus) 2005 stock assessment. National Oceanic and Atmospheric Administration, Chesapeake Bay Office, Annapolis, Maryland.

High, W. L., and D. D. Worlund. 1979. Escape of king crab Paralithodes camtschatica from derelict pots. NOAA (National Oceanic and Atmospheric Administration) Technical Report NMFS SSRF-734.

Lipcius, R. N., and W. T. Stockhausen. 2002. Concurrent decline of the spawning stock, recruitment, larval abundance, and size of the blue crab in Chesapeake Bay. Marine Ecological Progress Series 226:45-61.

Matsuoka, T., T. Nakashima, and N. Nagasawa. 2005. A review of ghost fishing: scientific approaches to evaluation and solutions. Fisheries Science 71:691-702.

McBride, M. 2006. Managed fisheries of the Chesapeake Bay. Pages 13-79 in NOAA Chesapeake Bay Fisheries Ecosystem Advisory Panel. Fisheries ecosystem planning for Chesapeake Bay. American Fisheries Society, Bethesda, Maryland.

McDougall, K. D. 1943. Sessile marine invertebrates of Beaufort, North Carolina: a study of settlement, growth, and seasonal fluctuations among pile-dwelling organisms. Ecological Monographs 13:321-374.

Miller, T. J. 2001a. Matrix-based modeling of blue crab population dynamics with applications to the Chesapeake Bay. Estuaries 24:535-544.

Miller, T. J. 2001b. The precautionary approach to managing blue crab in Chesapeake Bay: establishing limits and targets. Final Report to the Bi-State Blue Crab Advisory Committee, University of Maryland Center for Environmental Science, Chesapeake Bay Laboratory 01-0168, Cambridge.

Miller, T., S. Martell, D. Bunnell, G. Davis, L. Fegley, A. Sharov, C. Bonzek, D. Hewitt, J. Hoenig, and R. Lipcius. 2005. Stock assessment for blue crab in Chesapeake Bay. University of Maryland Center for Environmental Science Technical Report Series Number TS-487-05, Cambridge.

Poon, A. 2005. Haunted waters: an estimate of ghost fishing of crabs and lobsters by traps. Master's thesis. University of British Columbia, Canada.

Roosenburg, W. M., W. Cresko, M. Modesitte, and M. B. Robbins. 1997. Diamondback terrapin (Malaclemys terrapin) mortality in crab pots. Conservation Biology 11:1166-1172.

Shively, J. D. 1997. Degradability of natural materials used to attach escapement panels to blue crab traps in Texas. Texas Parks and Wildlife Department. Final Report SK Project NA67FD0034, Austin.

Smolowitz, R. J. 1978. Trap design and ghost fishing: an overview. U.S. National Marine Fisheries Service Marine Fisheries Review 40:1-8.

Turner, H. V., D. L. Wolcott, T. G. Wolcott, and A. H. Hines. 2003. Post-mating behavior, intramolt growth, and onset of migration to Chesapeake Bay spawning grounds by adult female blue crabs, Callinectes sapidus Rathbun. Journal of Experimental Marine Biology and Ecology 295:107-130.

Van Engel, W. A. 1982. Blue crab mortalities associated with pesticides, herbicides, temperature, salinity, and dissolved oxygen. Pages 187-194 in H. M. Perry and W. A. Van Engel, editors. Proceedings blue crab colloquium. Gulf States Marine Fisheries Commission, Publication 7, Ocean Springs, Mississippi.

VMRC (Virginia Marine Resources Commission). 2006. VMRC sales of commercial license by calendar year. VMRC, Newport News, Virginia. Available: www.mrc. state.va.us. (December 2006).

Whitaker, D. 1979. Abandoned crab trap study. South Carolina Wildlife and Marine Resources Report, Columbia. 